\title{
OPPORTUNITIES AND BARRIERS REGARDING THE DEVELOPMENT OF REGIONAL BEAN PRODUCTION WITH GEOGRAPHICAL CERTIFICATION IN POLAND
}

\author{
Agnieszka Borowska, $\mathrm{PhD}^{1}$
}

Faculty of Economic Sciences, Warsaw University of Life Sciences - SGGW

\begin{abstract}
The objective of the study is to present opportunities and barriers concerning the development of regional bean production with geographical indication and designation of origin, in Poland, in 2012-2017. The specificity, scale and conditions of production of three Polish regional bean species are described including the background of changes in the area cultivated with bean, its yield, production and development of buying-in prices. Attention is drawn to objective and subjective factors slowing down the certification process of leguminous crop production in accordance with producer specification. Information from the following databases has been used in the study: FAOSTAT, Eurostat, GUS (Central Statistical Office), JIHARS (Agricultural and Food Quality Inspection), as well as the following associations of regional bean producers (Association of Climbing Bean 'Piękny Jaś' Producers in Wrzawy, Association of Bean Producers in Nowy Korczyn, Cooperative 'Dolina Dunajca' and LAG (Local Action Group) 'Biała-Dunajec'). The niche character and small previous production volume mean that regional beans PDO and PGI are only available in season for a small group of consumers. Little interest from producers of production certification makes it difficult to recognize that this pro-development activity is rather amateur at the current stage of building the regional food market in Poland.
\end{abstract}

Key words: regional beans, production, price

JEL code: Q11

\section{INTRODUCTION}

The multiflora bean is grown exclusively for dry seeds in Poland (Deska, 2016). As regards production and consumption, the most widespread are white beans, i.e. the climbing bean 'Piękny Jaś tyczny', the dwarf bean 'Piękny Jaś karłowy', white beans with a uniform white colour and multi-coloured ones. There are three species of multiflora beans among forty Polish products protected in the EU, found within the framework of the food quality policy of the European quality scheme for agricultural products and foodstuffs, such as Protected Designation of Origin (PDO), Protected Geographical Indication (PGI) or Traditional Speciality Guaranteed (TSG). Their seeds are those of large beans. One thousand beans of 'fasola Pięknego Jasia z Doliny Dunajca Fasola z Doliny Dunajca', registered on 25 October 2011 as PDO, weighed up to $2-2.8 \mathrm{~kg}$, 'fasola wrzawska', registered on 13 January 2012 as PDO weighed around

${ }^{1}$ Corresponding author: Nowoursynowska S166, 02-787 Warsaw, Poland, Agnieszka_Borowska@SGGW.pl, +4822 5934030 (38). 
$2 \mathrm{~kg}$ and 'fasola korczyńska', registered on 13 July 2010 as PGI with a weight of $1-1.6 \mathrm{~kg}$ (European Commission, 2018).

\section{MATERIALS AND METHODS}

The objective of this article is to present the situation of regional bean on the Polish market, with particular regard to bean holding a recognized EU geographical certification - with protected designation of origin and geographical indication. Primary and secondary sources of information were used in the study. The first came from research conducted in 2012, 2014 and February-April 2016 by all three associations of the certified and non-certificated agricultural producer of: 'fasola Piękny Jaś z Doliny Dunajca' (PDO), 'fasola wrzawska' (PDO) and 'fasola korczyńska' (PGI) - in the form of a survey questionnaire. Statistical reports used in this study included data from the Ministry of Agriculture and Rural Development, Agricultural and Food Quality Inspection - Main Inspectorate and Central Statistical Office, FAOSTAT, Eurostat, GUS and the European Commission. In the analysis of research, comparative and descriptive methods were used.

\section{RESULTS AND DISCUSSION}

Private farms in Poland regard the bean as a crop that diversifies production, however, some growers specialize in its cultivation. Most decide to sell beans early in the season to entities specializing in buying in (most often for export), distributing or processing the crop, in order to generate additional income in the household budget as soon as possible. It is the scale of production, the organization level of agricultural holdings (operating individually or in the framework of associations, etc.) that determines the use of contractual advantage gained by the buyer vis-à-vis the supplier or vice versa, which is less frequent. Farmers did not have any problems selling beans, especially in 2008-2014. Buying-in entities were able to purchase total production (meeting domestic processing industry demand; while approximately 37,500 t were exported) (INTRASTAT, 2016), though the intermediation of logistic companies or the direct collection by processing enterprises (offering for instance advisory services and supply of agricultural inputs) was also observed. In 2017, the area covered by beans was 18,000 ha. The acreage made up $25.2 \%$ of the area cultivated with pulses for grains.

Table 1. Production, yield, area grown to bean in Poland in 2004-2017

\begin{tabular}{|c|c|c|c|c|c|c|c|}
\hline \multirow[b]{2}{*}{ Years } & \multicolumn{3}{|c|}{ Bean } & \multirow[b]{2}{*}{$\begin{array}{l}\text { Production of } \\
\text { pulses for human } \\
\text { consumption } \\
\text { (thous. t) }\end{array}$} & \multirow{2}{*}{$\begin{array}{c}\text { Share of bean } \\
\text { acreage in area } \\
\text { grown to pulses } \\
\text { for } \\
\text { human } \\
\text { consumption } \\
(\%)\end{array}$} & \multirow{2}{*}{$\begin{array}{l}\text { Share of bean } \\
\text { production in } \\
\text { pulses for human } \\
\text { consumption } \\
\text { production } \\
(\%)\end{array}$} & \multirow[b]{2}{*}{$\begin{array}{c}\text { Share of bean } \\
\text { purchase in total } \\
\text { bean production } \\
(\%)\end{array}$} \\
\hline & $\begin{array}{l}\text { produc- } \\
\text { tion } \\
\text { (thous. } \mathrm{t} \text { ) }\end{array}$ & $\begin{array}{c}\text { yield } \\
(\mathrm{dt} / \mathrm{ha})\end{array}$ & $\begin{array}{c}\text { area } \\
\text { (thous. } \\
\text { ha) }\end{array}$ & & & & \\
\hline 2004 & 37.9 & 18.6 & 20.4 & 76.6 & 57.1 & 49.5 & 12.3 \\
\hline 2007 & 38.8 & 19.4 & 20.1 & 75.2 & 57.1 & 51.6 & 14.9 \\
\hline 2010 & 33.4 & 18.7 & 17.8 & 87.5 & 40.7 & 38.2 & 20.2 \\
\hline 2012 & 29.3 & 21.7 & 13.5 & 85.2 & 39.1 & 34.4 & 17.0 \\
\hline 2014 & 38.4 & 22.0 & 17.5 & 115.4 & 32.9 & 33.3 & 21.1 \\
\hline 2015 & 40.7 & 15.7 & 25.8 & 171.5 & 28.4 & 23.7 & 26.0 \\
\hline 2017 & 49.9 & 27.7 & 18.0 & 173.2 & 26.8 & 28.8 & 27.1 \\
\hline
\end{tabular}

Source: own calculations based on GUS (2004-2018). 
Proceedings of the 2018 International Scientific Conference 'Economic Sciences for Agribusiness and Rural Economy' No 1, Warsaw, 7-8 June 2018, pp. 133-139

Table 2. Average prices of bean for human consumption and purchasing power of average monthly remuneration in Poland in 2005-2015

\begin{tabular}{|l|c|c|c|c|c|c|c|}
\hline Specification & 2010 & 2011 & 2012 & 2013 & 2014 & 2015 & $\begin{array}{c}\text { Changes } \\
2005-2014\end{array}$ \\
\hline $\begin{array}{l}\text { Average buying-in prices of beans for human } \\
\text { consumption (PLN/kg) }\end{array}$ & 3.44 & 3.83 & 4.18 & 5.63 & 4.83 & 3.64 & 164.2 \\
\hline $\begin{array}{l}\text { Average prices of bean obtained by farmers at } \\
\text { market places (PLN/kg) }\end{array}$ & 6.1 & 7.0 & 7.3 & 8.2 & 9.3 & 9.4 & 206.9 \\
\hline Average retail prices of small white bean (PLN/kg) & 7.37 & 8.12 & 8.46 & 9.30 & 10.76 & n.d. & 180.5 \\
\hline $\begin{array}{l}\text { Purchasing power of average monthly remuneration } \\
\text { relative to beans available at market places (kg) }\end{array}$ & 529 & 486 & 482 & 445 & 407 & 415 & 59.82 \\
\hline $\begin{array}{l}\text { Purchasing power of average monthly remuneration } \\
\text { relative to small white bean in retail sale (kg) }\end{array}$ & 438 & 419 & 416 & 392 & 352 & 346 & 74.16 \\
\hline
\end{tabular}

Source: calculations based on GUS (2015).

The yield was $27.7 \mathrm{dt} / \mathrm{ha}$ and was by $0.9 \mathrm{dt} / \mathrm{ha}$ (3.4\%) higher than in the previous year (2016). Bean production totalled $49,900 \mathrm{t}$ - the largest in the period under examination, 2004-2017, accounting for 28.8\% of total pulse production (Table 1). Since Poland's accession to the EU, the retail price of bean was from around 50 to $120 \%$ higher than the wholesale price. From 2005 to 2014, the average price of small white bean in retail trade rose by $80.5 \%$ and that of bean sold directly by farmers at market places - by $107 \%$, whereas bean paid for by buying-in entities - by $64 \%$ (Table 2). Households in Poland in general can afford to buy bean (grains). Unfortunately, in 2016 average consumption of pulses was as low as approximately $0.5 \mathrm{~kg}$ per person in a household, whereas in the 1980s it was $5 \mathrm{~kg}$ (Podleśny and Magnuszewski, 2004) per person per annum, and by the end of 1990 s $-1.2 \mathrm{~kg}$ per person per annum. The biggest quantities were consumed by inhabitants of regions where cultivation of bean was most widespread, i.e. Małopolskie and Świętokrzyskie $(0.72 \mathrm{~kg} /$ person/year $)$ as well as Podkarpackie $(0.84 \mathrm{~kg} /$ person/year $)$.

\section{VOLUME AND VALUE OF PRODUCTION OF CERTIFIED REGIONAL BEANS}

Out of three Polish beans certified as PDO or PGI, 'fasola wrzawska PDO' has been the only one avail- able on the market from its registration date. The remaining two multiflora beans (stringed and climbing), i.e. 'fasola korczyńska PGI' and 'Piękny Jaś z Doliny Dunajca PGI' were not available on the market to consumers since the former was not cultivated by a certified producer and the latter was, in fact, occasionally available, mainly for promotion purposes as tasting panels. The certified bean was placed on the market mainly by producers of 'fasola wrzawska PDO', who belonged to the Association of Climbing Bean 'Piękny Jaś' Producers in Wrzawy. The Association was composed of 301 members in 2006, however, their number fell to a mere 26 in subsequent years. By 2011, right before bean certification as PDO, more than $50 \%$ of members were interested in certified production, at least this is what was declared, however only every third applied for the control of the production process, whereas in 2017 there were only six farmers (Table 3). Climbing Bean 'Piękny Jaś' is cultivated on small farms. In 2015, around 250 farmers in the village of Wrzawy alone, from which the name of the protected product originates, were involved in the production of non-certified beans, allotting on average approximately $0.5-0.7$ ha of the crop, and total production of approximately $25 \mathrm{t}$. However, as regards certified 'fasola wrzawska PDO', in 2012-2016, it was produced in agricultural holdings of an area of 4.5-4.6 ha, mainly 
Proceedings of the 2018 International Scientific Conference 'Economic Sciences for Agribusiness and Rural Economy' No 1, Warsaw, 7-8 June 2018, pp. 133-139

Table 3. Characteristics of producers and production of bean 'fasola wrzawska PDO' in 2012-2016

\begin{tabular}{|l|c|c|c|c|c|}
\hline Specification & 2012 & 2013 & 2014 & 2015 & 2016 \\
\hline Number of certified producers of 'fasola wrzawska PDO' & 11 & 10 & 10 & 10 & 10 \\
\hline Area grown to 'fasola wrzawska PDO' by certified producers (ha) & 7.9 & 8.7 & 9.9 & 10.5 & 11.0 \\
\hline $\begin{array}{l}\text { Estimated production volume of 'fasola wrzawska PDO' - sold } \\
\text { according to the Association of Climbing Bean 'Piękny Jaś' Producers } \\
\text { in Wrzawy (kg) }\end{array}$ & 950 & 1750 & 1600 & 1550 & - \\
\hline Estimated value of 'fasola wrzawska PDO' sales (PLN thous.) & 17.1 & 31.5 & 32.0 & 31.0 & - \\
\hline
\end{tabular}

Source: Stowarzyszenie Producentów Fasoli Tycznej 'Piękny Jaś' we Wrzawach/Association of Tyczna Bean 'Piękny Jaś' in Wrzawy.

in the Gorzyce municipality (10), and on plots of an area of $0.72-1.1$ ha located in Radomyśl municipality on the San River.

In the period under examination, when 'fasola wrzawska' with a PDO label was produced, its acreage increased by $14 \%$ (to $11 \mathrm{ha}$ ). In the course of 2012-2014, its average yield obtained by farmers ranged from 12 to $15 \mathrm{dt} /$ ha, whereas 2015 turned out to be worse as yields were at a level of $8.7 \mathrm{dt} / \mathrm{ha}$. Producers consider a good harvest to be from $150 \mathrm{~kg}$ to $200 \mathrm{~kg}$ beans obtained from 600 plants (i.e. $0.25-0.33$ $\mathrm{kg} /$ item). The sold production of 'fasola wrzawska PDO' totalled 5.85 t. In 2012, it became available under protected designation for the first time and then its volume sold was equal to $9.5 \mathrm{t}$, whereas in the following three years its sales amounted to 15.5-17.5 t. By the end of this period, the sales of bean with a PDO logo amounted to around PLN 111,600, of which PLN 17,100 was paid to farmers in the first year of production certification and PLN 31,000-32,000 in subsequent years (Borowska, 2010, 2017). The scale of total production was small; only eight producers placed up to $500 \mathrm{~kg}$ of the PDO bean on the market, while five sold from $510 \mathrm{~kg}$ to $1.2 \mathrm{t}$. None of the farm holdings specialized in this leguminous crop production and simply acted as a supplement to diversify basic production, generating additional, regular and real income from several to a dozen or so PLN thousand per 1 ha, annually. The two categories of multiflora beans cultivated in the Nadwiślańska Lowland and the Lower San Basin, i.e. the same variety - with or without the PDO label - were characterized by the same average price rise experienced by farmers in direct sales, in buying-in entities and at market places. Due to physical properties (e.g. the size of beans), the price of dwarf varieties ('piękny Jaś karłowy') on the local market was relatively lower in comparison with climbing beans ('piękny Jaś'), particularly those with large-size beans. In 2012-2015, the producers of 'fasola wrzawska PDO' distributed, in total, $20 \%$ more seeds via the direct sales channel, i.e. over $3.1 \mathrm{t}$, than via the indirect channel $-2.65 \mathrm{t}$. One third of farmers declared that the sale was carried out on the farm by themselves or by family members, and $23 \%$ - at nearby market places. It is worth noting that local retail store demand, on a one-off basis, was about $20-30 \mathrm{~kg}$ of the certified product, but it was more difficult to find a buyer of larger quantities (Tajs, 2013). At the beginning, it was assumed that through the promotion of bean with the EU PDO label, farmers would reduce the supply chain thanks to the Association (by eliminating intermediaries and tradesmen) and reach consumers directly with their product, thereby obtaining not only a price premium but also minimizing trade margin (Borowska, 2010; Tajs, 2013; Borowska, 2017). However, the presence of this link in the chain improved and accelerated the flow of goods, and therefore its complete elimination at this stage was not in the interest of the producers; moreover, it caused 'fasola wrzawska PDO' to become more recognizable and bought not only at the local market. The second Polish regional bean with the EU PDO logo available on the market is 'Piękny Jaś $\mathrm{z}$ Doliny Dunajca'. It is cultivated in eleven 
municipalities located within the administrative borders of the Małopolskie Voivodeship (province). In 2008 alone, the area grown to beans in the Dunajec Valley, in municipalities associated in the Union of Bean Producing Municipalities, was approximately 600 ha. The average farm size in the Tarnowskie district located in this Voivodeship is slightly more than 3 ha, whereas the acreage grown to beans by members of the 'Dolina Dunajca' cooperative, composed of 31 members, was in total 15 ha, i.e. on average 0.48 ha per person. A characteristic feature of the region was the allotment of plots from 20 acres to approximately 0.5 ha for bean cultivation. In favourable soil and meteorological conditions, during the growing season, the yield obtained in the plantations in the Dunajec Valley, depending on production technology, varied from 2 to $4 \mathrm{t} / \mathrm{ha}$. In 2008-2014 the production of non-certified bean in the 'Dolina Dunajca' cooperative amounted to nearly $20 \mathrm{t}$ and its estimated value ranged, depending on the year, from PLN 120,000 to 220,000 . In 2011 wholesale prices of non-certified beans paid to farmers were on average from 10 to $11 \mathrm{PLN} / \mathrm{kg}$, however the final level depended on the date of sale, the customer, product volume and calibration. In subsequent years, i.e. 2013-2014, producers were able to obtain 8-9 PLN/kg for fresh produce and $10-11 \mathrm{PLN} / \mathrm{kg}$ for dried beans. It turned out that the sale of bean 'Piękny Jaś', without the EU PDO label, was ensured every year due to activity on the local market of specialist buying-in entities, such as 'Florpak' Sp. z.o.o. (Wojnicz), 'TAR - GROCH-FIL', Vitapol, Baśpol and others. Until the product name was reserved, this bean variety had been sold on the market under the common name 'Piękny Jaś z Doliny Dunajca'. Producers were identified with it and had hopes for future economic benefits deriving from it. From 2011, the vegetable under the certified name 'fasola Piękny Jaś z Doliny Dunajca' was not sold or was sold in negligible, niche quantities. Although this variety of bean was still commonly cultivated in the Dunajec Valley following the same production methodology as before, the common, generic name, not the protected one, was used for grains of this leguminous crop, because the producers did not want to go through the certification procedure and control of the production process.
Just like 'fasola wrzawska PDO', 'fasola Piękny Jaś z Doliny Dunajca PDO’ provided an additional source of income; it was considered to be of economic importance - it enabled the maintainence of jobs in agriculture and helped create new ones for family firms connected with the product (collection, transport, export, processing, etc.). Furthermore, it constituted an important element of the concept of the development strategy under implementation of, for instance, the Tarnowski district. A precious local entrepreneurship initiative was undertaken, i.e. thanks to the Association GRUPA ODROLNIKA, sales were organized via a website http://www.odrolnika. $\mathrm{pl}$ / (the so-called parcel from a farmer in the online store www.paczkaodrolnika.pl). In addition, the Local Product Centre (CPL) in Rzuchowa was established to carry out the direct sale of, for example, traditional foodstuff (included in the List of Traditional Products (LPT) of the Ministry of Agriculture and Rural Development), and in 2015-2016 the bean 'Piękny Jaś z Doliny Dunajca PDO' was on offer there, too.

The third regional bean in Poland protected by geographical indication is 'fasola korczyńska'. However, it was not available on the market under this name. There were several reasons for this situation. Firstly, the Association of Bean Producers in Nowy Korczyn pointed out to the fact that the price fixed by the entities buying in beans only due to product geographical indication - 'fasola korczyńska PGI' was not higher, given the lack of full traceability in trade of the origin of the regional bean as a high quality product (e.g. by indicating on the package the name of the bean, its commercial standard; in the case of a mixture, the share of varieties together with their origin and structure; the name of the producer, site of production and packing). However, the price should be higher resulting from additional requirements imposed on producers upon certification (confirming production quality) and the value-added for the consumer - full product traceability at each stage 'from farm to fork'. Additional workload of the producers upon production, keeping registers identifying volume and sale would not constitute a barrier to obtaining a certificate. However, producers believed it was debatable whether the market was mature and developed enough for all entities involved in buying in and 
packaging bean bearing, in this case, the PGI logo to feel the necessity of putting in an additional effort to prove to authorities - potentially another, additional, new (e.g. marketable quality) control body in the company - all raw material suppliers, the quantity and origin of the bean, buyers and quantities of seeds sold as well as the bill for the amount of bean bought in and sold. The potential for this leguminous crop production under the name 'fasola korczyńska PGI' was considerable. In 2014 alone, there were over 7,330 farm holdings in the designated geographical area of its production, and about 1,200 persons from these holdings were members of the Association of Bean Producers in Nowy Korczyn. They allotted nearly 3,000 ha to vegetable cultivation and, depending on the year, approximately $80 \%$ of it, i.e. 2,400 ha, for the cultivation of stringed dwarf bean 'Piękny Jaś'. In 2007, in the Nowy Korczyn municipality alone, this bean was grown on around 700 ha of arable land. The requirement imposed on the 'fasola korczyńska PGI' producers to grow it on plots not less than 0.20 ha, whereas yield should not be higher than $20 \mathrm{dt} / \mathrm{ha}$. It is worth adding that, in 2009 alone, the area grown to beans was 2,500 ha, while production amounted to almost $800 \mathrm{t}$. The acreage of bean cultivated by members of the Association was about 650 ha, while production - nearly $1,600 \mathrm{t}$.

\section{DISCUSSION AND COMMENTS}

In the areas where regional bean with protected geographical certification could be cultivated, including Małopolskie Voivodeship ('fasola Piękny Jaś z Doliny Dunajca PDO'), Świętokrzyskie Voivodeship ('fasola korczyńska PGI'), Podkarpackie Voivodeship ('fasola wrzawska PDO'), there are thousands of agricultural holdings that have varieties of this leguminous crop within the structure of the area sown to crops. However, taking into account the dozen or so producers in total who submitted the application for certification and control of bean production according to specification, the scale is regarded as very modest. Moreover, in 2017 , there were, in total, only seven certified producers in Poland, including one of the bean 'fasola z Doliny Dunajca' and six of 'fasola wrzawska' with the possibility of selling the product with the EU PDO label and making use of the protected name. There were many objective and subjective reasons for this situation. The former were as follows: formally complex documentation, a time-consuming process of recording information necessary for comprehensive production control, making free samples available for laboratory tests of the product - the producer must bear additional costs of a control (about PLN $650-700$, i.e. as much as the farmer obtained from the sale of $50 \mathrm{~kg}$ of beans, while production was low several hundred kilogrammes). This was a significant, additional burden to the budget, as farmers had to wait for months for cost reimbursement provided they applied for such reimbursement under the measure 'Farmers' participation in food quality schemes' in the subsequent Rural development programmes: RDP 2007-2013, RDP 2014-2020. It is worth noting that the maximum reimbursement of eligible costs borne due to farmer participation in EU food quality schemes was 3,200 PLN annually per holding throughout the period of five years since entering the food quality scheme. Moreover, a lack of price premium satisfactory to producers for a high quality regional product (bearing the EU logo on a label) relative to non-certified bean offered on the market, etc., was observed. Subjective factors are another matter - additional obligations from the certification declaration, the attitude of an observer of the certification and control system functioning, the willingness to take a decision based on other farmer experience, no time to deal with additional administrative tasks and formalities connected with keeping product records and statistics, small production scale due to a lack of farm specialization, annual sale on a contract basis of beans not requiring certification, etc. One of the major reasons for relatively little interest in the crop were not very high and variable in year harvests, though high yield potential was great, but sensitivity to unfavourable weather and susceptibility to disease very often caused the yield to be low. Furthermore, bean production was an additional source of income for small agricultural holdings for which the production certification process became the goal of the formal sale of small quantities of the product bearing a protected EU symbol and it was an image-related benefit only, not an economic success. Little interest 
in growing PDO or PGI beans was the consequence of relatively favourable bean prices in 2011-2014 in both wholesale purchases and direct sale, while annual demand on the part of the wholesale purchase of goods (including large beans) intended for processing in Poland and for export remained unflagging.

\section{REFERENCES}

1. Borowska, A. (2010). Uwarunkowania ekonomiczne pozaekonomiczne produkcji żywności wysokiej jakości w Polsce [Economic and non-economic conditions for traditional food production in Poland]. Wydawnictwo SGGW, Warszawa.

2. Borowska, A. (2017). Uwarunkowania ekonomiczne i pozaekonomiczne konsumpcji żywności regionalnej w Polsce [Economic and non-economic conditions for regional food consumpotion in Poland]. Wydawnictwo SGGW, Warszawa.

3. Deska, D. (2016). Przedstawiamy popularne odmiany fasoli zwykłej i wielokwiatowej [We present popular types of common and multiflorous beans]. Retrieved from: http://www.rynek-rolny.pl/artykul [Accessed 20.07.2016].

4. INRASTAT (2016). Służba Celna Rzeczypospolitej Polskiej System - Informacja Taryfowa [Customs Serv- ice of the Republic of Poland. System - Tariff Information]. Retrieved from: http://isztar.mf.gov.pl/isztar/taryfa_celna [Accessed 21.01.2016].

5. Podleśny, J. (2003). Produkcja i wykorzystanie nasion roślin strączkowych w Polsce i innych krajach UE [Production and use of legume seeds in Poland and other EU countries]. Pamiętnik Puławski, 132, pp. 355-362.

6. Podleśny, J., Magnuszewski, T. (2004). Potrzeba więcej nasion roślin strączkowych [You need more legume seeds]. Poradnik Gospodarski, 9, pp. 24-25.

7. Podleśny, J. (2005). Rośliny strączkowe w Polsce - perspektywy uprawy i wykorzystanie nasion [Legumes in Poland - growing prospects and use of seeds]. Acta Agrophysica, 6 (1), pp. 213-224

8. Podleśny J. (2006). Produkcja i wykorzystanie nasion roślin strączkowych w Polsce i innych krajach UE [Production and use of legume seeds in Poland and other EU countries]. Wieś Jutra, 3, pp. 44-45.

9. Rudy, A. (2013). Jaś ma wzięcie. Fasola spod Tyszowiec i Mircza podbija świat. Tygodnika Zamojskiego of 28.08.2013. Retrieved from: http://www.tygodnikzamojski.pl/artykul [Accessed 27.08.2013].

10. Tajs, K. (2013). Udane święto fasoli we Wrzawach - było mnóstwo atrakcji i smakowitych potraw [A successful feast of beans in Wrzawy - there were plenty of attractions and tasty dishes]. Retrieved from: http:// fasola-wrzawska.prv.pl/aktualnosci.html. 